\title{
Determinants for the conservation of a vulnerable fire-dependent species at its marginal range
}

\author{
M. Moretti · C. Staehli · F. Gillet
}

Received: 3 October 2007/ Accepted: 26 February 2008/Published online: 15 March 2008

(C) Springer Science+Business Media B.V. 2008

\begin{abstract}
We investigated the role of fire and other potential biotic and abiotic determinants for the occurrence of an obligate seeder and active pyrophyte, Cistus salviifolius, a vulnerable species in the Swiss Red List. Populations of this species are threatened by the change of fire regime that has occurred during the last ten years. Fires and burnt areas are today less frequent and it is not clear whether other factors can compensate for such fire-free periods should this trend continue. We used a stratified random design to collect data on the cover of three growth stages, i.e., juvenile, chamaephytic and nanophanerophytic (oldest), of $C$. salviifolius, on plant communities, and on environmental factors. A tree-based discriminant analysis showed that the time elapsed since last fire was the best predictor of Cistus occurrence, but plants could survive on rocky and sunny sites if no fire had occurred for more than 32 years. Contrary to our expectations, the number of fires and time elapsed since the last event was correlated with the oldest stages only, and not with that of seedlings or juveniles. Rank correlations
\end{abstract}

M. Moretti $(\bowtie) \cdot$ C. Staehli

Swiss Federal Research Institute WSL, Ecosystem Boundaries Research Unit, Insubric Ecosystems Group, Via Belsoggiorno 22, 6500 Bellinzona, Switzerland e-mail: marco.moretti@wsl.ch

F. Gillet

EPFL Ecole Polytechnique Fédérale de Lausanne, Laboratory of Ecological Systems, Station 2 - Ecublens, 1015 Lausanne, Switzerland showed that bare soil was a good predictor of young stages, whereas rocky outcrops and shallow soils were important for the chamaephytic stage. Our results confirm the role of disturbances and competition-free habitats as determinants of the survival of this vulnerable pyrophyte during long periods without fires and the existence of ontogenetic niche segregation of this species. In order to maintain viable $C$. salviifolius populations in the Alps, managers should undertake conservation actions according to the requirements of the different growth stages of this species.

Keywords Cistus salviifolius · Disturbance · Fragmentation - Fire regime - Ontogenetic niche · Pyrophyte

\section{Introduction}

Predicting how the factors limiting the distribution and abundance of endangered species will change is one of the central tasks in conservation biology (Begon et al. 2006). Changes in fire regimes in many parts of the world seem to have had dramatic effects on the occurrence and distribution of many fragmented and endangered pyrophytic species, which depend on fire for reproduction (Bond et al. 2005). These species are often restricted to small and isolated populations in areas where fire suppression policies are in force, which in turn increases the fire-return intervals and 
leads to exhaustion of the seed-bank (Regan et al. 2003; Holmes and Newton 2004; Yates and Ladd 2005). In such conditions, the species are exposed to increasing fragmentation and extinction risk due to stochastic events or loss of the genetic variability due to high random genetic drift and low gene flow (Begon et al. 2006; Broadhurst and Young 2006).

The ecological effects of fire on pyrophytic plants are generally investigated in core fire-prone regions where fire represents the major driving force throughout the entire system (e.g. Bond et al. 2005). This makes the responses of fire-adapted species to changes in fire regimes difficult to isolate from responses to other environmental factors, such as land use change, and therefore, difficult to test and to interpret. Studies of species that naturally occur in small and fragmented populations on the margin of their geographic range where fire regime is variable in space and time might be more promising in this context (Lesica and Allendorf 1995; Nantel and Gagnon 1999; Lavergne et al. 2005).

The Sageleaf Rockrose (Cistus salviifolius) on the southern slopes of the Swiss Alps is ideally suited for such a study, being a pyrophytic obligate seeder (Naveh 1974) and living in small and patchy populations at the northern-most part of its distribution (Lauber and Wagner 2001). Cistus salviifolius is characterized by small seed size, hard-coatedness, short-distance dispersal, long-term persistence in soil seed banks, fire- or heat-induced seed 'softening', slow germination rate of soft seeds (Thanos and Georghiou 1988), and short longevity of the plants (approx. 15 years, Troumbis and Trabaud 1986). Under natural conditions, the dormancy of the seed bank is most likely to be released massively by wildfires (e.g. Nadal et al. 2002), often resulting in prolific dense stands (Roy and Sonié 1992; Legrand 1992; Tárrega et al. 2001; Quintana et al. 2004).

This pyrophytic pioneer is not endangered in the core area of the fire-prone Mediterranean region, while it shows great vulnerability at its northern range boundary, where fires are more fragmented than in the Mediterranean area. The Sageleaf Rockrose is protected in Northern Italy (Conti et al. 1997) and Redlisted in Switzerland as vulnerable (Moser et al. 2002).

A recent study by Moretti et al. (2006) on the potential distribution of $C$. salviifolius on the southern slopes of the Swiss Alps showed that, on a large spatial scale $\left(625 \mathrm{~m}^{2}\right.$ resolution), site conditions (i.e. annual potential evapotranspiration, slope, topographic position and rock coverage) were the most important predictors, while fire was a secondary predictor. They supported Trabauld's (1995) claim that $C$. salviifolius might not be an obligate pyrophilous seeder, at least at the edge of its distribution area.

This large-scale approach is of great interest for highlighting the major determinants of the potential distribution of a species, but it suffers from some limitations as it ignores processes occurring on a small spatial scale (Wiens 1989). In particular, fires may have very different effects on the performance of a fragmented population in a heterogeneous habitat with various vegetation types and transition zones between heathland and clear forest (Staehli 2005). Population dynamics is likely to be affected by competition and facilitation processes within local plant communities, as well as by other sources of disturbance linked to management. Moreover, these processes may act differently across growth stages of a shrub species such as C. salviifolius (e.g. Eriksson 2002).

The aim of this article is to examine, on a small spatial scale, the effects of abiotic and biotic determinants on the occurrence and dominance of $C$. salviifolius at the northern-most range of its distribution area. In order to address this issue, we tried to predict the abundance of $C$. salviifolius from the fire history of the past 40 years and from other site conditions, including the composition of the surrounding plant communities. We tested the following hypotheses: (i) fire remains the best environmental predictor of the overall local occurrence of $C$. salviifolius for any growth stages, and even at the northern edge of its distribution area; (ii) C. salviifolius is more abundant at sites where fire occurs frequently, and the young stages occur mainly in recently burnt sites; (iii) when the time interval between fires is long, C. salviifolius at its northernmost range limit is more likely to survive in areas where there are less competitors, such as rocky outcrops and disturbed areas.

\section{Methods}

Study area

The study area is located in the region of Locarno in southern Switzerland between $46^{\circ} 06^{\prime}$ and $46^{\circ} 33^{\prime} \mathrm{N}$, 
Fig. 1 Distribution of Cistus salviifolius (black patches) in the study area on the southern slopes of the Swiss Alps at the northernrange distribution of the species in Europe. Grey patches show the fire distribution in the study area during the period 1968-2004. The white circles are the sampling plots $(n=84)$, see Methods. The black patches C. salviifolius without plots are inaccessible places, such as very steep slopes and vertical rock walls where the species grows in slits and on small ledges

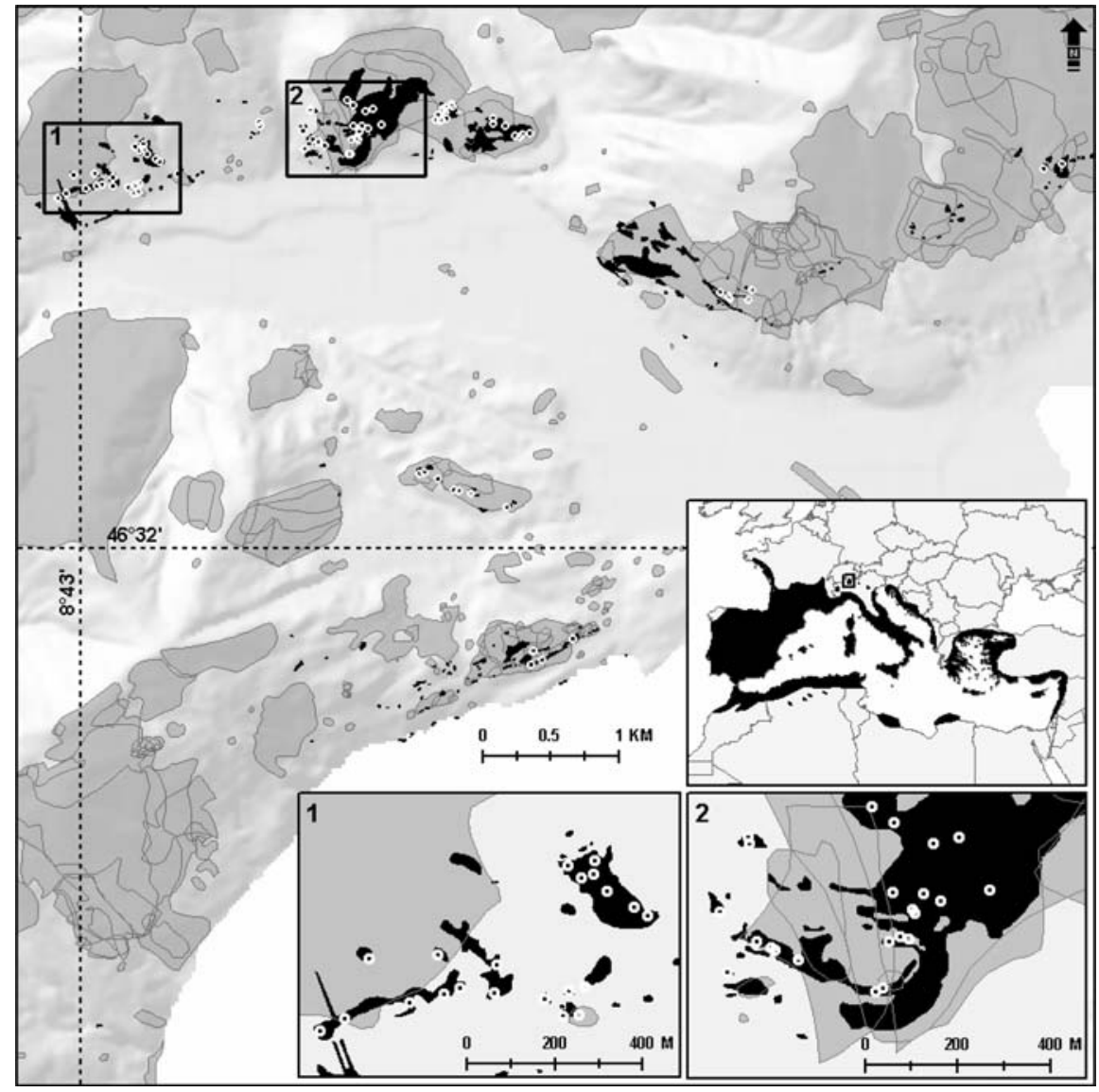

and between $8^{\circ} 42^{\prime}$ and $8^{\circ} 51^{\prime}$ E (Fig. 1), which corresponds to the main distribution area of Cistus salviifolius in Switzerland (Moretti et al. 2006).

This region is part of the Emerald Network of Areas of Special Conservation Interest in the Alps, and is considered an important biodiversity area.

The climate is mainly moist and warm temperate, with a mean annual temperature of about $12^{\circ} \mathrm{C}$ (January approx. $2-3^{\circ} \mathrm{C}$ and July approx. $21-22^{\circ} \mathrm{C}$ ). Mean annual precipitation is $1600-1700 \mathrm{~mm}$, and is higher in summer (ca. $800 \mathrm{~mm}$ from June to September) than in winter (ca. $400 \mathrm{~mm}$ from November to February). In contrast to more southerly regions with a Mediterranean climate and a medium to intensive summer fire regime, the Southern slopes of the Alps are prone to fast-spreading surface fires of low to medium intensity during the period of vegetation dormancy (December-April). Tinner et al. (1999) suggested that southern Switzerland, and probably all the south slopes of the Alps, are fire-prone areas and that fire must be considered to have been a natural environmental factor since the Paleolithic. In the last decade, the fire regime has changed quite dramatically due to more efficient fire prevention and fire fighting measures. As a consequence, the frequency and the mean burnt area have been dramatically reduced, dropping from 91 fires and 910 ha per year in the period 1968-1990, to 57 fires and 357 ha per year in the period 1991-2002 (Conedera and Pezzatti 2005).

The landscape of the study area is mainly dominated by former coppice stands of sweet chestnut (Castanea sativa Mill.) with oak (Quercus sp.) and other deciduous tree species on siliceous soil. It also contains patchily distributed rocky outcrops where most of the $C$. salviifoliius populations and other warmth-demanding and stress-tolerant plant species live (Staehli 2005).

\section{Sampling design}

The vegetation within the fragmented $C$. salviifolius population was sampled using a stratified random 
Table 1 Study plots grouped in three classes according to the number of fires between 1968 and 2004 and five classes according to the time elapsed since the last fire $(1-5 ; 6-10 ; 11-$ $20 ; 21-35$; $>35$ years)

\begin{tabular}{llccccc}
\hline N fires & \multicolumn{4}{l}{ Time elapsed since the last fire (years) } & Total \\
\cline { 2 - 5 } & $1-5$ & $6-10$ & $11-20$ & $21-35$ & $>35$ & \\
\hline 0 & & & & & 28 & 28 \\
1 & 1 & 3 & 10 & 14 & & 28 \\
$\geq 2$ & 2 & 19 & 3 & 4 & & 28 \\
Total & 3 & 22 & 13 & 18 & 28 & 84 \\
\hline
\end{tabular}

design based on the number of fires and time elapsed since the last fire in the previous 35 years (Table 1). It was not possible to balance the latter properly, particularly for the earliest category, due to the change in fire regime during the last 10 years.

The study area included all patches of the fragmented population and was stratified into three classes according to the number of fires. Within each of the three classes, 28 plots at least $5 \mathrm{~m}$ apart and $3 \mathrm{~m}$ from the margin of $C$. salviifolius patches were randomly selected, giving a total of 84 plots (Fig. 1). The plots were considered independent observations, since $C$. salviifolius disperses seeds up to 50-60 cm (Troumbis and Trabaud 1986). At each plot the plant community was sampled within a radius of $1.78 \mathrm{~m}\left(10 \mathrm{~m}^{2}\right)$. In lowdensity Cistus patches, it might happen that the species was not present within the plot. This was interpreted as an absence of $C$. salviifolius in that local plant community. The vegetation, including $C$. salviifolius if present, was divided into five vertical layers: short herbs and chamaephytes (height $\leq 0.5 \mathrm{~m}$ ), tall herbs and nanophanerophytes $(0.5-1.5 \mathrm{~m})$, microphanerophytes (1.5-3 m), mesophanerophytes $(3-5 \mathrm{~m})$, and megaphanerophytes ( $\geq 5 \mathrm{~m}$ ). The $C$. salviifolius height in the study area was always lower than $1.5 \mathrm{~m}$. The growth stages of $C$. salviifolius were classified as: young stages ' $y$ ' (i.e. seedlings and juveniles), chamaephytic stage ' $\mathrm{H}$ ' (height $\leq 0.5 \mathrm{~m}$ ) and nanophanerophytic stage ' $\mathrm{s}$ ' $(0.5-1.5 \mathrm{~m})$. The latter can be considered the most vigorous stage in the study area, while the chamaephytic stage may include different situations, such as suboptimal site conditions, regular cutting, browsing or senescence. Therefore, such stages defined by height classes do not correspond strictly to age classes but they represent a meaningful structural status of the species in the plant community.
Each species within each layer, including C. salviifolius stages, was assigned a Braun-Blanquet dominance code based on absolute cover $(+: \leq 1 \%, 1$ : 1-5\%, 2: 5-25\%, 3: 25-50\%, 4: 50-75\%, 5: 75-100\%). The vegetation was sampled in May-June and again in July-August 2004, in order to identify as many species as possible and to include species with different life cycles. Species nomenclature follows the Swiss Flora Synonymous Index of Aeschimann and Heitz (1996).

Various environmental and spatial variables were recorded for each plot (Table 2). Three variables (number of fires, time elapsed since the last fire, clear cutting) were related to disturbance, ten variables described other local site conditions (e.g. altitude, aspect, rocky outcrops and soil texture), one (patch size) was related to fragmentation of the $C$. salviifolius populations and two (longitude and latitude) were geographical coordinates.

\section{Data analysis}

Data analyses were designed to find relationships among C. salviifolius, fire, habitat fragmentation and local site factors. All analyses were conducted treating the 84 plots as independent observations, after checking for non-significant spatial autocorrelation for Cistus dominance using Mantel correlogram and permutation tests (Legendre and Legendre 1998) (not shown; see Staehli 2005 for more details).

The influence of environmental variables on the overall local occurrence of $C$. salviifolius was modelled using a Classification Tree, a powerful tool to identify important predictors of different types, either quantitative or qualitative (Heylen et al. 2005; Seoane et al. 2005; Wilson et al. 2005). The model was applied to predict the presence/absence of any stage of $C$. salviifolius (binary response variable) from disturbance, fragmentation and local site conditions as explanatory variables (Table 2).

The bivariate monotonic relationship between the absolute cover (deduced from dominance codes) of each stage of $C$. salviifolius and each explanatory variable was tested using Kendall's tau rank correlation. This measures the strength of the relationship between two quantitative or semi-quantitative variables (Legendre and Legendre 1998). The area of the population patch was log-transformed to reduce the effects of extreme values. The relationship between Cistus abundances and categorical explanatory variables (i.e. TOPO and CuT) 
Table 2 List of the environmental variables recorded in each plot

\begin{tabular}{|c|c|c|c|c|}
\hline Category & Abbreviations & Type & Unit or value & Description \\
\hline \multirow[t]{3}{*}{ Disturbances } & NFIRE & Quantitative & \# & Number of fires \\
\hline & TFIRE & Quantitative & $\mathrm{y}$ & Time since the last fire \\
\hline & Cut & Binary & {$[0,1]$} & Evidence of clearing activities \\
\hline \multirow[t]{10}{*}{ Local site conditions } & SLOPE & Quantitative & $\%$ & Average slope \\
\hline & Alt & Quantitative & m a.s.1. & Altitude \\
\hline & EAST & Quantitative & {$[-1: 1]$} & Eastness (sine of aspect in radians) \\
\hline & NORTH & Quantitative & {$[-1: 1]$} & Northness (cosine of aspect in radians) \\
\hline & Topo & Semi-quantitative & {$[1 ; 2 ; 3]$} & $\begin{array}{l}\text { Microtopographical convexity } \\
\qquad(1=\text { concave, } 2=\text { flat, } 3=\text { convex })\end{array}$ \\
\hline & SoILD & Quantitative & $\mathrm{cm}$ & Soil depth (median of 10 measurements) \\
\hline & BsolL & Quantitative & $\%$ & Bare soil area \\
\hline & Rock & Quantitative & $\%$ & Rocky outcrops area \\
\hline & LiTtER & Quantitative & $\%$ & Litter accumulation on the ground area \\
\hline & Sun & Quantitative & $\mathrm{h}$ & $\begin{array}{l}\text { Potential insolation from April to September } \\
\text { (measured with a solar compass) }\end{array}$ \\
\hline Fragmentation & PopArea & Quantitative & $\mathrm{m}^{2}$ & $\begin{array}{l}\text { Population area in which the sampling plots } \\
\text { were randomly located }\end{array}$ \\
\hline \multirow[t]{2}{*}{ Location } & COORDX & Quantitative & $\mathrm{km}$ & Longitudinal kilometric coordinate \\
\hline & COORDY & Quantitative & $\mathrm{km}$ & Latitudinal kilometric coordinate \\
\hline
\end{tabular}

Number of fires and time elapsed since the last fire refer to a 35-year time span (1968-2004)

was tested using nonparametric analyses of variance (Kruskal-Wallis $H$ ), since the requirements for ANOVA could not be met.

The relationship between abundances of $C$. salviifolius and other species of the community was investigated using Kendall's rank correlation between cover measurements. The ecological meaning of the species with a significant rank correlation, either positive or negative, with each stage of $C$. salviifolius is discussed in the light of the habitat requirements of the species, the ecological traits and fire syndromes. All statistical analyses were performed using $R$ 2.3.1 (R Development Core Team 2006).

\section{Results}

During the field survey in 2004, a total of 94 vascular plant species were found. Of these 36 (38\%) occurred only in one plot. Cistus salviifolius occurred in 58 of the 84 plots $(69 \%)$, of which 41 were burnt and 17 unburnt, while it did not occur in 15 burnt and 11 unburnt plots.

Figure 2 shows the classification tree for overall occurrence of $C$. salviifolius with two classes

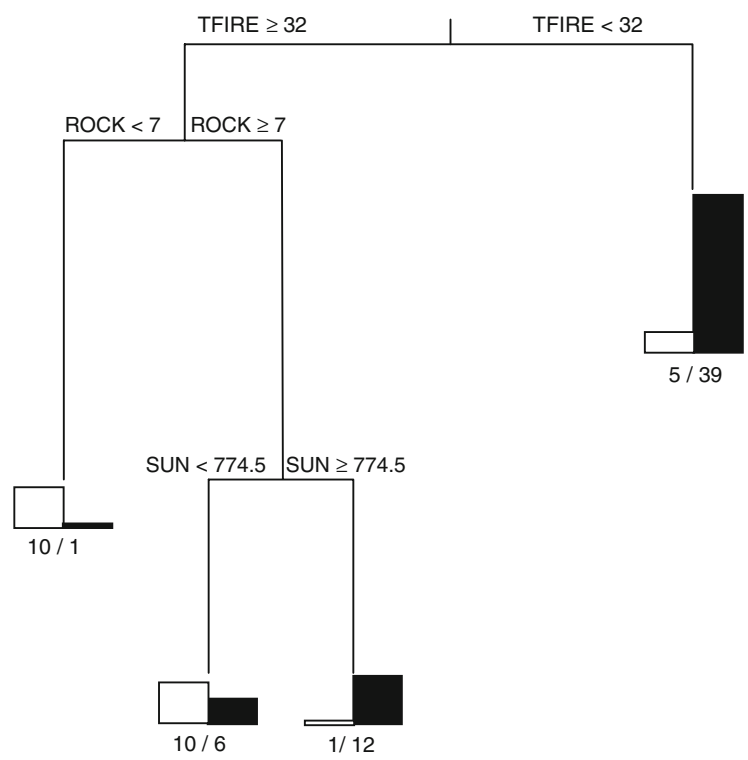

Fig. 2 Classification tree predicting the overall occurrence of Cistus salviifolius in the 84 plots. It can be read from top to bottom as a decision tree: each split divides the data into two subsets of objects according to a threshold for the selected predictor. Values and bars at each terminal node represent the number of plots in which the species was present (black bars) and absent (white bars), respectively. The abbreviations of the selected predictors are shown in Table 2 
(presence or absence, all stages included). The tree consists of three splits, with 4 terminal nodes which contain the number of plots for each class. The misclassification rate was $15 \%$ for the model, and $26 \%$ after cross-validation using the "leave-one-out" strategy. Time elapsed since the last fire, rocky outcrops and insolation were found to be explanatory variables. The interpretation of this decision tree is as follows: C. salviifolius occurs mainly in sites where the time elapsed since the last fire was less than 32 years; or alternatively when rocky outcrops were higher than $7 \%$ and potential insolation during the vegetation period was longer than $774.5 \mathrm{~h}$.

The environmental variables (see Table 2) showed various correlations with $C$. salviifolius cover in its different growth stages (Table 3). The juvenile stage was positively correlated only with bare soil area (Bsoll) and favoured by cutting (CUT). The chamaephytic stage was positively linked to rocky outcrops (Rock), cutting (CuT), shallow soil (SoILD), number of fires (NFIRE) and negatively correlated with time elapsed since last fire (TFIRE). The nanophanerophytic stage was also correlated with fire in the same way, but it was also positively correlated with potential insolation (Sun), local Cistus population area (PopA REA), and negatively to the northern component of aspect (NоRTH). All these variables, except bare soil and rocky outcrop area, were all also correlated with the overall dominance of $C$. salviifolius, while the litter cover (LiTTER) was the only variable that correlated exclusively with the overall Cistus cover, but not with the separate growth stages.

Table 4 shows the plant species associated with the different growth stages of $C$. salviifolius. The juvenile stage was positively associated with three herbaceous species of nutrient-poor and dry meadows (Danthonia decumbens, Peucedanum oreoselinum and Chrysopogon gryllus), and with early stages of two pioneer ligneous species, i.e. Robinia pseudoacacia, an invasive alien species in Europe, and Frangula alnus, an indigenous species. Surprisingly, no significant relationship was found between the juvenile and the oldest stages (i.e. chamaephytic and nanophanerophytic).

The chamaephytic stage was positively associated with the nanophanerophytic stage and three heathland species (Cytisus scoparius, Solidago virgaurea and Calluna vulgaris), and four species of nutrient-poor and dry meadows (Danthonia decumbens, Chrysopogon gryllus, Hypochaeris radicata and Silene rupestris). A negative association was found with Molinia arundinacea, a very competitive species in disturbed habitats.

The nanophanerophytic stage was positively correlated with Cytisus scoparius in its shrub stage. A negative association was found with Molinia arundinacea and two competitive tree species in their shrub stages (Castanea sativa and Quercus pubescens).
Table 3 Relationships between environmental variables and the cover of Cistus salviifolius at three different growth stages: seedling-juvenile, chamaephytic, and nanophanerophytic stages

Kendall's rank correlations

Tau on quantitative

variables, except \#, which correspond to $\mathrm{H}$ of

Kruskal-Wallis chi-squared (non-parametric one-way analysis of variance). *: $P<0.05$; **: $P<0.01$; ***: $P<0.001$. See Table 2 for abbreviations of the variables

\begin{tabular}{|c|c|c|c|c|}
\hline \multirow[t]{2}{*}{ Variables } & \multicolumn{4}{|c|}{ Cistus salviifolius growth stages } \\
\hline & $\begin{array}{l}\text { Seedling-juvenile } \\
\text { Tau or H }\end{array}$ & $\begin{array}{l}\text { Chamaephytic } \\
\text { Tau or H }\end{array}$ & $\begin{array}{l}\text { Nano-phanerophytic } \\
\text { Tau or H }\end{array}$ & Total cover \\
\hline BsoIL & $0.25 * *$ & 0.16 & -0.05 & 0.04 \\
\hline Cut & ${ }^{\#} 8.74 * *$ & ${ }^{*} 7.98 * *$ & ${ }^{\#} 0.43$ & ${ }^{\#} 7.45^{* *}$ \\
\hline ROCK & 0.06 & $0.18^{*}$ & 0.03 & 0.05 \\
\hline SoILD & -0.11 & $-0.21^{*}$ & -0.12 & $-0.17 *$ \\
\hline NFIRE & 0.03 & $0.19^{*}$ & $0.26^{* *}$ & $0.29 * * *$ \\
\hline TFIRE & -0.10 & $-0.18^{*}$ & $-0.31 * * *$ & $-0.32 * * *$ \\
\hline Sun & -0.07 & 0.10 & $0.25^{* *}$ & $0.19 *$ \\
\hline PopAREA & 0.06 & 0.07 & $0.22 * *$ & $0.17 *$ \\
\hline NORTH & -0.16 & -0.13 & $-0.20^{*}$ & $-0.20 *$ \\
\hline LITTER & -0.02 & -0.14 & -0.13 & $-0.19^{*}$ \\
\hline ТоРо & ${ }^{\#} 1.81$ & ${ }^{\#} 2.62$ & ${ }^{\#} 0.73$ & ${ }^{\#} 2.63$ \\
\hline EAST & 0.03 & -0.01 & -0.05 & -0.05 \\
\hline SLOPE & -0.04 & 0.08 & 0.03 & 0.06 \\
\hline Alt & -0.06 & -0.13 & -0.03 & -0.08 \\
\hline
\end{tabular}


Table 4 Kendall's rank correlations between the cover of Cistus salviifolius at every growth stage and the cover of the other species sampled at the 84 plots

Only species with at least two occurrences and one significant rank correlation are listed. Stg = growth stage; $\mathrm{y}=$ seedlingjuvenile; $\mathrm{h}=$ herb; $\mathrm{H}=$ dwarf shrub or chamaephytic stage (height $\leq 0.5 \mathrm{~m}$ ); $\mathrm{s}=$ small shrub $(0.5-3 \mathrm{~m})$; $\mathrm{S}=$ tall shrub (3-5 m);

Tau $=$ Kendall's rank correlation coefficient; *: $P<0.05$;** $P<0.01$; $* * *: P<0.001$

\begin{tabular}{|c|c|c|c|c|}
\hline \multirow[t]{2}{*}{ Species } & \multirow[t]{2}{*}{ Stg } & \multicolumn{3}{|c|}{ Cistus salviifolius growth stages } \\
\hline & & $\begin{array}{l}\text { Seedling-juvenile } \\
\text { Tau }\end{array}$ & $\begin{array}{l}\text { Chamaephytic } \\
\text { Tau }\end{array}$ & $\begin{array}{l}\text { Nano-phanerophytic } \\
\text { Tau }\end{array}$ \\
\hline Frangula alnus & $\mathrm{y}$ & $0.295 * *$ & -0.061 & -0.006 \\
\hline Robinia pseudoacacia & $\mathrm{H}$ & $0.286^{* *}$ & 0.119 & 0.162 \\
\hline Peиcedanum oreoselinum & $\mathrm{h}$ & $0.248^{*}$ & 0.160 & 0.050 \\
\hline Chrysopogon gryllus & $\mathrm{h}$ & $0.256^{*}$ & $0.243 *$ & 0.125 \\
\hline Danthonia decumbens & $\mathrm{h}$ & $0.215^{*}$ & $0.262 * *$ & 0.030 \\
\hline Cytisus scoparius & $\mathrm{H}$ & 0.025 & $0.297 * *$ & 0.103 \\
\hline Calluna vulgaris & $\mathrm{H}$ & 0.083 & $0.186^{*}$ & 0.059 \\
\hline Hypochaeris radicata & $\mathrm{h}$ & 0.079 & $0.189 *$ & 0.081 \\
\hline Solidago virgaurea & $\mathrm{h}$ & -0.079 & $0.241 *$ & 0.004 \\
\hline Silene rupestris & $\mathrm{h}$ & 0.124 & $0.229 *$ & 0.114 \\
\hline Molinia arundinacea & $\mathrm{h}$ & -0.016 & $-0.233 * *$ & $-0.167 *$ \\
\hline Cytisus scoparius & $\mathrm{s}$ & 0.083 & 0.159 & $0.242 * *$ \\
\hline Castanea sativa & $\mathrm{S}$ & -0.077 & -0.093 & $-0.248 * *$ \\
\hline Quercus pubescens & $\mathrm{S}$ & 0.076 & -0.052 & $-0.244 * *$ \\
\hline Castanea sativa & $\mathrm{s}$ & -0.067 & -0.131 & $-0.230^{*}$ \\
\hline Populus tremula & $\mathrm{h}$ & -0.084 & 0.031 & $0.197^{*}$ \\
\hline Cistus salviifolius & $\mathrm{H}$ & 0.141 & $1.000 * * *$ & $0.196^{*}$ \\
\hline Cistus salviifolius & $\mathrm{s}$ & 0.157 & $0.196^{*}$ & $1.000 * * *$ \\
\hline
\end{tabular}

\section{Discussion}

In the Mediterranean region, the Sageleaf Rockrose (Cistus salviifolius) is considered an active pyrophytic species and its distribution is related to the local fire history and fire regime (Naveh 1974; Troumbis and Trabaud 1986; Nadal et al. 2002). Our results confirmed that these findings also apply at local scale $\left(10 \mathrm{~m}^{2}\right)$ in our study area in Southern Switzerland at the northern range margin in the Alps.

These results are of particular interest because a large-scale $\left(625 \mathrm{~m}^{2}\right)$ distribution model of C. salviifolius drawn for the same region in a previous study (Moretti et al. 2006) showed that fire played a secondary role, while site conditions (e.g. slope, topographic position and rock coverage) were the major predictors. We suggest, therefore, that the small-scale model better reflects the role played by fire in the regeneration of $C$. salviifolius, where it releases the dormancy of the low dispersal hard-coat seeds (i.e. $<0.6 \mathrm{~m}$ around the mother plants; Thanos and Georghiou 1988) in situ (Troumbis and Trabaud 1986; Thanos et al. 1992).

Fire is not only a trigger for seed germination, but it is also an important driving factor behind vegetation dynamics (Trabaud 1995). This function is particularly important with regard to invasive alien species, such as Robinia pseudoacacia, and other pioneer species associated with $C$. salviifolius (e.g. Prunus avium, Fraxinus excelsior, Populus tremula) since they are very sensitive to fire (Delarze et al. 1992; Tinner et al. 2000).

Our results showed an unexpectedly high threshold of 32 years after the last fire in explaining $C$. salviifolius occurrence. This time span is more than twice as long as the life span of $C$. salviifolius, which is about 15 years (Troumbis and Trabaud 1986). This suggests that some of the plants on the edge of their range live longer than 15 years or that regeneration of $C$. salviifolius may possibly take place independent of fire.

In our study, the abundance of young stages was not correlated with fire, but rather with clear-cutting and bare soil. Thus mechanical clearing seems to be temporarily able to mimic the early post-fire conditions where much of the biomass has been burnt, exposing bare soil for successful germination (Tárrega et al. 2001). Spontaneous seedling recruitment and vegetative resprouting of $C$. salviifolius at unburnt sites have already been observed in the Mediterranean region by various authors (e.g. Naveth 
1974; Roy and Sonié 1992; Thanos et al. 1992), while germination tests have confirmed that about $20-30 \%$ of the seeds germinate without any treatment (Thanos and Georghiou 1988; Nadal et al. 2002).

Overall, our results show that the different growth stages of C. salviifolius populations in the Alps respond to different environmental factors, which may provide evidence for an ontogenetic niche segregation (Grubb 1977). Ontogenetic niche shift has been well explored for animals (e.g. Post 2003; Takimoto 2003), but rarely for plants (see Eriksson 2002 for a review). However, it is well known that niche requirements of shrubs and trees (Béguin 2007) can change during their lifetimes. They are, however, unable to move, and thus are constrained to live under the conditions that prevail at the site where they originally established. Any changes in local environmental characteristics, or even simply interactions with other species, may mean the plants adjust their niche requirements during their different growth stages. This adjustment may play an important role by optimizing resource exploitation at each growth stage, while minimizing the energy costs (Miriti 2006).

In our study, the recruitment niche (Young et al. 2005) exploited by the seedling-juvenile stages of $C$. salviifolius was merely characterized by bare soil. This is usually more widespread following a disturbance, such as mechanical removal of vegetation (as shown in our study) or fire. But fire was surprisingly not correlated with young stages of $C$. salviifolius. This clearly indicates that not only has there been a lack of fires during the last 3-5 years, when high seedling recruitments are expected, but also that distinct niches were occupied by the juvenile and the adult stages. Adult stages tended, in fact, to be found in areas that had been previously disturbed by fires.

Within the reproductive niche, where adults meet, produce flowers and seeds (Young et al. 2005), our results showed two further specific niches of $C$. salviifolius. The first, which was exploited by the chamaephytic stages, was mainly characterized by rocky environments and shallow soil. It is therefore affected by extreme xerothermic conditions, as confirmed by positive association between this Cistus stage and xerothermophilous plant species, such as Chrysopogon gryllus, Danthonia decumbens and Silene rupestris. Rock outcrops appear, however, to have a double positive indirect effect. They are favourable by selecting a stress-tolerant, open and short vegetation so that there is little competition for light (e.g. from trees and tall herbs, such as Molinia arundinacea). They also provide suitable microclimate conditions for this Mediterranean species, i.e., warm in summer and mild in winter (Lauber and Wagner 2001).

The second reproductive niche, which was mainly occupied by the nanophanerophytic stage of $C$. salviifolius, was characterized by intermediate and less extreme conditions positively associated with mesophilic species (e.g. Populus tremula, Calluna vulgaris and Cytisus scoparius). Here nanophanerophytic stages occurred in large insolated and southexposed areas, forming dense stands where competitive species, such as Molinia arundinacea, Quercus pubescens and Castanea sativa, were absent, although a few pioneer species, such as Populus tremula, have started to colonize the area.

\section{Conclusion}

In this study, we have shown that fire represents one of the most important driving forces for the local occurrence and distribution of $C$. salviifolius at the northern range limit of its distribution in the Alps, where local fire regimes differ substantially from those typical of the Mediterranean species' core area. Recruitment and reproductive niches do not correspond to the same environment, indicating ontogenetic niche segregation. The adult stages (i.e. the chamaephytic and nanophanerophitic stages) occupy distinct niches. This suggests that there is an additional niche differentiation, which may hide some unexplored life strategies that are of great conservation and evolutionary value in the peripheral C. salviifolius populations in the Alps. Local site conditions (especially rocky outcrops) were likely to ensure the long-term persistence of $C$. salviifolius for up to twice as long as the estimated life span of the species, buffering it against local extinction. Keeley (1977) suggested that occasional long fire-free periods are an important evolutionary stimulus for the obligate seedling strategy.

Understanding the effect of these processes on the population's range margin could help in assessing the ability of the species to cope with changes and stress, and this could have an overall positive impact on the long term conservation of the species as shown by 
Channell and Lomolino (2000) for most of the 245 species, of which range contraction in Australia was examined.

Further studies of the dynamic persistence of $C$. salviifolius population's range margin are therefore required to clarify to what extent population structure and fire are linked. Moreover, we need to know more about the relationship between fire regimes and seed bank persistence, and about the role of inter-fire recruitment in maintaining populations during long fire-free periods at the edge of $C$. salviifolius distribution area. Meanwhile urgent conservation measures are highly recommended in order to ensure that $C$. salviifolius has a long-term future on the Swiss southern slopes of the Alps. Mechanical clearing and adequate prescribed burns should be applied to ensure that stands can remain persistent and viable in the long term.

Acknowledgements We would like to thank Andrea Persico for his help in checking some plant identifications, Marco Conedera and Jean-Daniel Gallandat for their useful suggestions during the project, and Damiano Torriani for providing GIS data. Our thanks are also due to Patrick Fonti for critical feedback which has, we believe, improved the article. We acknowledge two anonymous reviewers for their detailed comments on the first version of the manuscript and we are grateful to Silvia Dingwall and Robert Home for her help during its revision.

\section{References}

Aeschimann D, Heitz C (1996) Synonymie-Index der Schweizer. Flora Documenta Floristicae Helveticae. vol 1. Zentrum des Daten-Verbundnetzes der Schweizer Flora CRSF/ZDSF, Neuchâtel

Begon M, Harper JL, Colin CR (2006) Ecology: individuals populations and communities. Blackwell Science, Oxford

Béguin D (2007) Tree regeneration and growth in wood pastures: patterns and processes. Dissertation, University of Neuchâtel

Bond WJ, Woodward FI, Midgley GF (2005) The global distribution of ecosystems in a world without fire. New Phytol 165:525-538

Broadhurst LM, Young AG (2006) Reproductive constraints for the long-term persistence of fragmented Acacia dealbata (Minosaceae) populations in southeast Australia. Biol Conserv 133:512-526

Channell R, Lomolino M (2000) Dynamic biogeography and conservation of endangered species. Nature 403:84-86

Conedera M, Pezzatti B (2005) Gli incendi di bosco: cosa dice la statistica. In: Venturelli E (ed) Dati statistiche e società. vol 1. Ufficio Statistica del Cantone Ticino, Bellinzona, pp 6-13

Conti F, Manzi A, Pedrotti F (1997) Liste rosse regionali delle piante d'Italia. WWF Italia. Soc Bot Ital. Camerino
Delarze R, Caldelari D, Hainard P (1992) Effects of fire forest dynamics in southern Switzerland. Veg Sci 3:55-60

Eriksson O (2002) Ontogenetic niche shifts and their implications for recruitment in three clonal Vaccinium shrubs: Vaccinium myrtillus, Vaccinium vitis-idaea, and Vaccinium oxycoccos. Can J Bot 80:635-641

Grubb P (1977) The maintenance of species richness in plant communities: the importance of the regeneration niche. Biol Rev 52:107-145

Heylen O, Hermy M, Schrevens E (2005) Determinants of cryptogamic epiphyte diversity in a river valley. Biol Conserv 126:371-382

Holmes PM, Newton RJ (2004) Patterns of seed persistence in South African fynbos. Plant Ecol 172:143-158

Keeley JE (1977) Seed production seed populations in soil and seedling production after fire for two congeneric pairs of sprouting and non-sprouting chaparral shrubs. Ecology 58:820-829

Lauber K, Wagner G (2001) Flora Helvetica. Haupt Verlag AG, Bern

Lavergne S, Thuiller W, Molina J, Debussche M (2005) Environmental and human factors influencing rare plant local occurrence extinction and persistence: a 115 years study in the Mediterranean region. J Biogeogr 32:799-811

Legendre P, Legendre L (1998) Numerical ecology. 2nd edn. Elsevier, New York

Legrand C (1992) Regeneration of two Cistus species after prescribed burning. In: Trabaud L, Prodon R (eds) Fire in mediterranean ecosystems. Ecosystems research report. vol. 5. ECSC EEC EAEC, Brussels-Luxembourg, pp 183-192

Lesica P, Allendorf FW (1995) When are peripherial populations valuable for conservation? Conserv Biol 9:753-760

Miriti MN (2006) Ontogenetic shift from facilitation to competition in a desert shrub. J Ecol 94:973-979

Moretti M, Conedera M, Moresi R, Guisan A (2006) Modelling the influence of change in fire regime on the local distribution of a Mediterranean pyrophytic plant species (Cistus salviifolius) at its northern range limit. $\mathrm{J}$ Biogeogr 33:1492-1502

Moser DM, Gygax A, Bäumler B, Wyler N, Palese R (2002) Lista Rossa delle specie minacciate della Svizzera Felci e piante a fiori Ufficio federale dell' ambiente delle foreste e del paesaggio, Berna

Nadal P, Sanchis E, Perez-Garcie F, Fos M (2002) Effects on dry-heat soaking in distilled water and gibberellic acid on the germination of Cistus clusii, $C$ monpeliensis and $C$ salviifolius seeds. Seed Sci Technol 30:663-669

Nantel P, Gagnon D (1999) Variability in the dynamics of northern peripherical versus southern populations of two clonal plant species Heliantus divaricatus and Rhus aromatica. J Ecol 87:748-760

Naveh Z (1974) Effects of fire in the Mediterranean Region. In: Kozlowski TT, Ahlgren CE (eds) Fire and ecosystems. Academic Press, New York, pp. 401-434

Post DM (2003) Individual variation in the timing of ontogenetic niche shifts in largemouth bass. Ecology 84:12981310

Quintana JR, Cruz A, Fernandez-Gonzalez F, Moreno JM (2004) Time of germination and establishment success after fire of three obligate seeders in a Mediterranean shrubland of central Spain. J Biogeogr 31:241-249 
R Development Core Team (2005) R: A language and environment for statistical computing $\mathrm{R}$ Foundation for Statistical Computing. Vienna Austria. URL http://www. R-project.org. Cited 12 February 2006

Regan HM, Auld TD, Keith DA, Burgman MA (2003) The effects of fire and predators on the long-term persistence of an endangered shrub Grevillea caleyi. Biol Conserv 109:73-83

Roy J, Sonié L (1992) Germination and population dynamics of Cistus species in relation to fire. J Appl Ecol 29:647655

Seoane J, Carrascal LM, Alonso CL, Palomino D (2005) Species-specific traits associated to prediction errors in bird habitat suitability modelling. Ecol Modell 185:299308

Staehli C (2005) Ecologie et phytosociologie du Cistus salviifolius L au Tessin (Southern Switzerland). Diploma Thesis, University of Neuchâtel

Takimoto G (2003) Adaptive plasticity in ontogenetic niche shifts stabilizes consumer-resource dynamics. Am Nat 162:93-109

Tárrega R, Luis-Calabuig E, Valbuena L (2001) Eleven years of recovery dynamics after experimental burning and cutting in two Cistus communities. Acta Oecol 22:277-283

Thanos CA, Georghiou K (1988) Ecophysiology of fire-stimulated seed germination in Cistus incanus ssp. creticus (L.) Heywood and C. salviifolius L. Plant Cell Environ 11:841-849
Thanos CA, Kadis C, Pantazi C (1992) Cistaceae: a plant family with hard seeds. Israel J Bot 41:251-263

Tinner W, Hubschmid P, Wehrli M, Ammann B, Conedera M (1999) Long-term forest-fire ecology and dynamics in southern Switzerland. J Ecol 87:273-289

Tinner W, Conedera M, Gobet E, Hubschmid P, Wehrli M, Ammann B, (2000) A palaeoecological attempt to classify fire sensitivity of trees in the southern Alps. The Holocene 10:565-574

Trabaud L (1995) Germination of Mediterranean Cistus spp. and Pinus spp. and their reoccupation of disturbed sites. Rev Ecol (Terre Vie) 50:3-14

Troumbis A, Trabaud L (1986) Comparison of reproductive biological attributes of two Cistus species. Acta Oecol 7:235-250

Yates CJ, Ladd PG (2005) Relative importance of reproductive biology and establishment ecology for persistence of a rare shrub in a fragmented landscape Conserv Biol 19:239-249

Young TP, Petersen DA, Clary JJ (2005) The ecology of restoration: historical links emerging issues and unexplored realms. Ecol Lett 8:662-673

Wiens JA (1989) Spatial scaling in ecology. Funct Ecol 3:385397

Wilson K, Newton A, Echeverría C, Weston C, Burgman M (2005) A vulnerability analysis of the temperate forests of south central Chile. Biol Conserv 122:9-21 